\title{
Kredit Bermasalah Untuk Meningkatkan Profitabilitas Busn Non Devisa Go Public
}

\author{
W.Agustina, A. Surachim \\ Universitas Pendidikan Indonesia \\ widia.agustina94@student.upi.edu
}

\begin{abstract}
The purpose of this research is to study the NPL research and Profitability. This research was carried out in a period of five years, for banks, in the design of the research framework used is historical data, against samples without random using historical data, then the design of this study uses a combined design. This study uses descriptive and verification methods with hypothesis testing methods and data analysis techniques using panel data regression. The Findings of Problem Credit refers to Profitability. This difference is determined in the independent variables, objects and research methods, participation and research samples, research period, measurement tools and research results, as well as sources of theory and foreign journals and foreign books and research results
\end{abstract}

\footnotetext{
ABSTRAK

Tujuan penelitian ini yaitu untuk mengetahui pengaruh Kredit Bermasalah dan Profitabilitas. Penelitian ini dilakukan dalam rentang lima tahun, untuk sepuluh bank, dalam rangka desain penelitian yang digunakan adalah data historis, terhadap sample tanpa random dengan menggunakan data historis, maka desain penelitian ini menggunakan pooled design. Penelitian ini menggunakan pendekatan deskriptif dan verifikatif dengan metode hipotesis test serta teknik analisis data menggunakakn regresi data panel. Temuan Kredit Bermasalah ini berpengaruh terhadap Profitabilitas. Perbedaan ini ditentukan dalam variabel independen, objek dan metode penelitian, populasi dan sampel penelitian, periode penelitian, alat ukur dan hasil penelitian, serta sumber teori dan jurnal asing dan buku asing serta hasil penelitian
}

\author{
ARTICLE INFO: \\ Article history: \\ Received 12 Desember 2016 \\ Revised 13 Desember 2016 \\ Accepted 15 Desember 2016 \\ Available online $12 \mathrm{Mei}$ \\ 2017
}

\author{
Keywords: \\ Non Performing Loan (NPL), \\ Problem Loans, \\ Profitability, \\ Return On Asset (ROA).
}

\section{Kata Kunci: \\ Kredit Bermasalah, \\ Non Performing Loan, \\ Profitabilitas, \\ Return On Assets}

\section{PENDAHULUAN}

Profitabilitas sebagai analisis rasio kinerja keuangan merupakan hal yang penting untuk menunjukan kemampuan perusahaan dalam mendapatkan keuntungan maksimal atau laba atas investasi (Lesáková, 2007). Tanpa adanya kemampuan perusahaan dalam mecapai laba, maka perusahaan tidak dapat menarik modal luar, sehingga baik pemilik, kreditor, dan manajemen keuangan akan sangat memperhatikan tingkat keuntungan untuk kepentingan di dalam pasar keuangan (Gitman Chad, 2014).

Profitabilitas masih menjadi masalah yang banyak diteliti dalam bidang keuangan untuk memberikan ukuran tingkat efektivitas manajemen suatu perusahaan (Kasmir, 2015) dan umumnya dianggap sebagai prasyarat penting bagi kelangsungan hidup perusahaan jangka panjang dalam mencapai keberhasilan (Yazdanfar, 2013). Pengguna informasi biasanya melihat keberhasilan suatu perusahaan dari kondisi keuangan dan kinerja keuangan yang dimilikinya. Salah satu cara untuk mengetahui kinerja keuangan yang sehat pada suatu perusahaan adalah dengan melihat kemampuan perusahaan dalam memperoleh keuntungan melalui rasio profitabilitas (Devi, 2011).

Penelitian tentang profitabilitas telah diteliti pada berbagai bidang industri seperti yang dilakukan oleh (Adeusi \& Kolapo, 2014) pada industri perbankan, menyatakan bahwa kualitas asset, efisiensi manajemen, dan pertumbuhan ekonomi merupakan faktor penentu profitabilitas bank umum. 
Kemudian penelitian yang dilakukan oleh (Berrada, Loudiyi, \& Zorkani, 2017) tentang profitabilitas pada perusahaan energi menyatakan bahwa untuk menganalisis risiko profitabilitas yang terkait dengan proyek tersebut, digunakan analisis sensitivitas. Penelitian selanjutnya dilakukan pada perusahaan jasa yang menghasilkan uji kelayakan model dari variabel struktur modal yang terdiri atas debt ratio (DAR), debt to equity ratio (DER), longterm to debt assets ratio (LDAR), longterm debt to equity ratio (LDER) mempunyai pengaruh signifikan terhadap profitabilitas (ROE) (Ali, 2016). Sedangkan pada sektor perdagangan yang menguji pengaruh kredit perdagangan terhadap profitabilitas memberikan bukti empiris bahwa penerapan kredit perdagangan secara signifikan dan negatif mempengaruhi profitabilitas perusahaan, sedangkan tingkat likuiditas dan ukuran perusahaan secara positif berpengaruh dengan profitabilitas, sementara bobot perusahaan berpengaruh secara negatif dengan profitabilitas (Yazdanfar \& Öhman, 2016). Selanjutnya penelitian pada industri klorin nasional merekomendasikan perusahaan untuk memiliki departemen independen yaitu manajemen akuntansi untuk membantu menganalisis profitabilitas perusahaan (Dalabeeh, 2013).

Salah satu industri yang masih mengalami masalah cukup signifikan adalah pada industri perbankan (Bougatef, 2017). Sejak krisis keuangan global tahun 2008 yang mengakibatkan runtuhnya pasar keuangan dan lembaga keuangan maka stabilitas perbankan dinilai sangat penting, karena berakibat pada peningkatan keseluruhan tingkat stress di sektor perbankan (Swamy, 2013). Profitabilitas selama empat dekade terakhir masih menjadi masalah yang banyak diteliti di bank konvensional (Haron \& Azmi, 2004). Sejak penelitian pertama oleh Hester (1966), yang mengukur hubungan antara item dalam neraca dan laba bank di Amerika Serikat, studi profitabilitas bank kemudian berkembang ke tingkat internasional diantaranya: (Molyneux \& Thornton, 1992), (Asli Demirguc-Kunt and Harry Huizinga, 2000), (Goddard, Molyneux, \& Wilson, 2008), (Duraj \& Moci, 2015), dan (Trad, Trabelsi, \& Goux, 2016).

Sistem perbankan yang kuat dan stabil tergantung pada tingkat profitabilitas dan regulasi dari setiap keputusan bank yang berpengaruh pada setiap pemangku kepentingan (stake holder) (Weon Lee, 2015). Profitabilitas berperan menjaga kapasitas keuntungan produktif yang merupakan faktor penting yang berkontribusi terhadap kelangsungan hidup organisasi yang menunjukkan seberapa efisien manajemen dapat meraih keuntungan dengan menggunakan semua sumber daya yang tersedia di pasar (Mehta \& Bhavani, 2017). Profitabilitas dianggap faktor utama dalam mempengaruhi reputasi perusahaan (Srinivasan \& Thiru, 2015). Kapasitas pinjaman dari perusahaan juga ditentukan oleh keuntungan. Tingkat profitabilitas harus tetap dijaga dan ditingkatkan untuk mengatasi masalah (Sriyana, 2015).

Pengukuran rasio profitabilitas terdiri atas beberapa indikator yaitu, Net Profit Margin (NPM), Gross Profit Margin (GPM), Basic Earning Power (BEP), Return On Assets (ROA) atau Return On Investment (ROI), dan Return On Equity (ROE) (Wild, 2010). ROA paling sering digunakan dalam literatur perbankan, dengan alasan sebagai proksi kinerja asset bank secara langsung dan mencerminkan tingkat pendapatan maupun pengeluaran (Olson \& Zoubi, 2011). ROA tidak bervariasi sesuai dengan jumlah leverage yang dipekerjakan, seperti halnya ROE (Golin, 2013). ROA merupakan salah satu metode paling populer dan bermanfaat dari rasio keuangan. ROA telah digunakan dalam industri setidaknya sejak tahun 1919 , ketika perusahaan Du Pont mulai menggunakan pendekatan khusus untuk analisis rasio agar dapat mengevaluasi efektivitas perusahaan tersebut. Rasio ini digunakan sebagai puncak sistem segitiga rasio. Rasio ini disebut laba atas investasi dan dihitung sebagai Laba dibagi Jumlah Aktiva (Jewell \& Mankin, 2011).

Profitabilitas bank umum konvensional yang diproyeksikan dalam Return On Assets saat ini dinilai berada dalam tekanan selama periode 2014 sampai 2015 dan diperkirakan berlanjut pada tahun 2016. Otoritas Jasa Keuangan sebagai lembaga yang mengawasi aliran dana ekonomi perbankan dan non perbankan mengemukakan bahwa laporan tahunan yang menyajikan ihtisar rasio profitabilitas perbankan masih mengalami penurunan. Adapun pertumbuhan Return On Assets selama periode 2011-2015 menunjukan bank umum konvensional yang terdiri atas bank pemerintah, BUSN Devisa, BUSN Non Devisa, bank asing, dan bank campuran pada kurun waktu 2013 mengalami fluktuasi dengan tren yang menurun. Penurunan yang terus menerus terjadi sejak tahun 2013, di mana penurunan antara 20132014 sebesar $0.23 \%$, kemudian dilanjutkan pada 
tahun 2014-2015 di mana pertumbuhan return on assets sebagai instrumen pencapaian profitabilitas menurun sebesar $0,53 \%$.

Perkembangan ROA pada 10 BUSN

Non Devisa Go Public periode 2011-2015 berdasarkan laporan tahunan menunjukan bahwa perkembangan ROA rata-rata mengalami fluktuasi yang menurun, dengan rata-rata penurunan terjadi pada tahun 2012-2015. Dua bank yang berada pada posisi terendah menghasilkan rasio ROA di bawah $0 \%$ yaitu Bank Harda Internasional dan Bank Pundi. Hal ini, menunjukan adanya masalah pada profitabilitas, di mana berdasarkan data di atas posisi ROA masih banyak yang berada di bawah ketentuan standar BI yang menetapkan 1,5\% untuk penilaian ROA bank.

$$
\text { Menurut teori Brigham }
$$

(2014)menyatakan bahwa rasio profitabilitas menunjukan kombinasi pengaruh dari likuiditas, manajemen asset, dan utang terhadap hasil operasi. Faktor yang mempengaruhi profitabilitas tingkat mikro merupakan variabel internal dari spesifikasi perbankan diantaranya (Masood \& Ashraf, 2012) : total Assets, risiko keuangan, kecukupan modal, manajemen kredit, efisiensi operasional, kualitas assets, manajemen assets, likuiditas, deposito. Adapun pada tingkat makro diantaranya : faktor eksternal perusahaan/perbankan, pertumbuhan, dan inflasi. Menurut (Iskandar, 2013:117), profitabilitas ditentukan oleh volume atau besarnya jumlah kredit yang diberikan. Berdasarkan ketentuan Bank Indonesia, beberapa faktor yang memiliki pengaruh terhadap profitabilitas perbankan, diantaranya: Capital Adequacy Ratio (CAR), Non Performing Loan (NPL), Biaya Operasional dan Pendapatan Operasional (BOPO), Net Interest Margin (NIM), dan Loan to Deposit Ratio (LDR).

Menurut (Haneef, Rana, \& Karim,

2012) Rasio yang digunakan untuk mengukur kredit bermasalah adalah Non Performing Loan dan Profitabilitas akan mencapai nilai maksimal jika Non Performing Loan sebagai rasio kredit bermasalah atas kualitas asset berada pada nilai yang rendah.

Tujuan penelitian ini adalah: (1) memperoleh temuan mengenai gambaran Non Performing Loan (NPL), (2) memperoleh temuan mengenai gambaran Profitabilitas Return On Asset (ROA).

\section{KAJIAN PUSTAKA Profitabilitas}

Setiap badan usaha memiliki tujuan meraih laba yang diperlukan untuk membiayai kegiatan operasional perusahaan maupun untuk memberikan imbal hasil bagi pemiliki modal (Kasmir, 2015). Kemampuan memperoleh keuntungan dikenal sebagai profitabilitas (Onuonga, 2014). Profitabilitas berkonotasi dimana pendapatan yang dihasilkan selama periode tertentu melebihi biaya yang dikeluarkan selama jangka waktu yang sama (Adagye, 2015). Terdapat dua jenis rasio profitabilitas dihitung berdasarkan penjualan dan investasi (Innocent, Mary, \& Matthew, 2013).

Definisi profitabilitas menurut yaitu efek bersih dari operasi bisnis selama periode waktu tertentu, sedangkan Gitman Chad (2014) menyatakan, bahwa profitabilitas adalah hubungan antara pendapatan dan biaya yang dihasilkan dengan menggunakan asset perusahaan, baik asset lancar dan tetap, dalam kegiatan produksinya. Profitabilitas diukur melalui rasio di mana rasio profitabilitas bertujuan untuk mengukur tingkat efisiensi penggunakaan aktiva atau sekelompok aktiva perusahaan (Husnan, 2006). Rasio profitabilitas adalah rasio yang menghubungkan laba dari penjualan dan investasi (Van Horne, 2016:180). Beberapa indikator yang dapat digunakan untuk mengukur profitabilitas adalah Gross Profit Margin (GPM) , Operating Profit Margin (OPM), Net Profit Margin (NPM), Return On Investement (ROI), Return On Equity (ROE), Return On Common Stock Equity (ROCSE), Earning Per Share (EPS), dan Basic Earning Power (BEP) ((Lukman, 2009b) ; Kasmir, 2015:199; Gitman Chad, 2014; Munawir, 2014:86, dan Brigham, 2015).

ROA (Return On Asset) merupakan rasio yang membandingkan laba bersih yang diterima oleh perusahaan dengan aktiva yang dimiliki perusahaan. Semakin besar ROA maka akan semakin baik, hal tersebut berarti bank dapat memanfaatkan aktiva yang dimiliki untuk dijadikan profit (Surachim, 2010). Tiberiu (2015) menyatakan, bahwa tingkat profitabilitas dapat dijelaskan oleh lima faktor, yaitu: Non Performing Loan (NPL), kapitalisasi, likuiditas, margin bunga dan biaya non-bunga.

\section{Kredit Bermasalah}

Tingkat kelangsungan usaha bank berkaitan erat dengan aktiva produktif yang dimilikinya. Kualitas aktiva produktif 
menunjukkan kualitas asset sehubungan dengan risiko kredit yang dihadapi oleh bank akibat pemberian kredit dan investasi dana bank (Nawaz, Muhammad., and Munir, 2012). Ketersediaan pinjaman bank yang selanjutnya disebut "kredit bank" adalah sebuah siklus dari pengelolaan kualitas asset suatu perbankan (Becker \& Ivashina, 2014). Setiap penanaman dana bank dalam aktiva produktif dinilai kualitasnya dengan menentukan tingkat kolektibilitas. Kolektibilitas dapat diartikan sebagai keadaan pembayaran kembali pokok, angsuran pokok atau bunga kredit oleh nasabah serta tingkat kemungkinan diterima kembali dana yang ditanamkan dalam surat berharga atau penanaman lainnya (Dash,M.K \& Kabra, 2010).

Bank melakukan penggolongan kredit menjadi dua jenis yaitu : Performing Loan dan Non Performing Loan (Ismail, 2011:122-123). Salah satu rasio yang harus diperhatikan perbankan adalah rasio Non Performing Loan sebagai indikator dari kredit bermasalah yang timbul akibat gagalnya pengelolaan risiko kredit. Menurut (SE/No.3/1/PBI/2011) tentang metode penilaian kinerja keuangan RGEC, kredit bermasalah merupakan variabel yang berasal dari risiko kredit yang memiliki indikator rasio Non Performing Loan.

Brigham Eugence dan Joel F.Houton, (2015) mengemukakan, bahwa risiko kredit merupakan suatu risiko akibat kegagalan atau ketidakmampuan nasabah mengembalikan jumlah pinjaman yang diterima dari bank beserta bunganya sesuai dengan jangka waktu yang telah ditetapkan atau dijadwalkan. Sedangkan menurut (Rivai, 2013), Non Performing Loan terjadi ketika adanya cidera janji dalam pembayaran kembali sesuai perjanjian, sehingga terdapat tunggakan atau terdapat potensi kerugian usaha debitur sehingga memiliki kemungkinan timbulnya risiko dikemudian hari bagi bank dalam arti luas. Kredit bermasalah pada bank jika tidak ditangani secara baik maka akan menjadi sumber kerugian bagi bank. Karena itu diperlukan penanganan yang sistematis dan berkelanjutan (Haneef et al., 2012).

Faktor-faktor yang menyebabkan kredit tersebut menjadi bermasalah, yaitu : 1) Faktor internal perbankan; 2) Faktor internal nasabah; 3) Faktor eksternal; 4) Faktor kegagalan bisnis; 5) Ketidakmampuan manajemen (Dendawijaya, 2009) dan (Heffernan, 2005). Salah satu teknik dalam menyelesaikan kredit bermasalah yaitu perbankan harus memiliki prinsip 5C sebagaimana dikemukakan oleh (Kasmir, 2015:253; Iskandar, 2013; Arbi, 2013) yang meliputi : 1)Character, untuk mengetahui sifat atau watak calon debitur; 2) Capacity, untuk menilai kemampuan calon debitur mengelola usaha; 3) Capital, untuk menilai kemampuan keuangan calon debitur; 4) Collateral, untuk menilai jaminan yang akan diberikan calon debitur; 5) Condition, untuk mengetahui prospek usaha saat ini dan yang akan datang dalam hubungannya dengan perkembangan ekonomi, moneter dan perbankan serta dampaknya terhadap kelangsungan usaha.

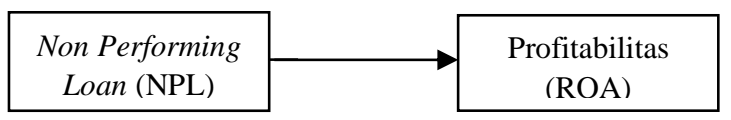

Gambar 1

Paradigma Penelitian

\section{METODE PENELITIAN}

Penelitian ini dilakukan untuk mengetahui pengaruh Kredit Bermasalah dan Profitabilitas. Variabel bebal (independent variable) yang terdapat pada penelitian ini yaitu Kredit Bermasalah dengan indikator Non Performing Loan (NPL), sedangkan variabel terikat (dependent variable) pada penelitian ini yaitu Profitabilitas dengan indikator Return On Asset (ROA).

Penelitian ini dilakukan pada BUSN Non Devisa Go Public periode 2011-2015. Desain penelitian yang digunakan yaitu Pooled Model Design dengan jenis penelitian verifikatif. Berdasarkan jenis penelitian tersebut, maka metode yang digunakan dalam penelitian ini adalah explanatory research yang bertujuan untuk menguji hipotesis antara variabel-variabel bebas degan variabel terikat. Teknik pengumpulan data yang digunakan adalah studi kepustakaan dan dokumentasi. Serta teknik analisis data menggunakakn regresi data panel.

\section{HASIL DAN PEMBAHASAN}

Kredit merupakan asset penting bagi BUSN Non Devisa Go Public periode 20112015, kontribusinya terhadap pendapatan operasional bank terus meningkat dan sejak tahun 2011 bunga kredit telah menjadi sumber pendapatan utama. Peran penting tersebut melahirkan tuntutan kepada manajemen untuk melakukan pengelolaan secara professional agar kesehatan atas pengelolaan risiko kredit bermasalah dapat ditekan pada level yang rendah 
dalam rangka menjamin pendapatan bank. Perkembangan kredit bermasalah dengan rasio NPL pada BUSN Non Devisa Go Public periode 2011-2015, menunjukan informasi bahwa kredit bermasalah BUSN Non Devisa Go Public mengalami pergerakan yang tidak stabil, beberapa bank mengalami kenaikan yang sangat tajam (ekstrim) pada periode 2013-2015 dengan rata-rata pencapaian NPL pada tahun 2011 sebesar $2,68 \%$, tahun 2012 sebesar $2,48 \%$, tahun 2013 mengalami penurunan sebesar 1,78\%, tahun 2014 kembali meningkat dengan pencapaian $2,47 \%$, dan terakhir tahun 2015 berada pada posisi $2,49 \%$. Nilai NPL tertinggi dialami oleh Bank Pundi yang mencapai nilai > $8 \%$ yang menunjukan predikat kurang baik dalam mengelola risiko kredit bermasalah.

Profitabilitas BUSN Non Devisa Go Public yang diukur dengan Return On Asset (ROA) periode 2011-2015 menunjukan bahwa perkembangan profitabilitas BUSN Non Devisa Go Public periode 2011-2015 mengalami penurunan yang sangat tajam pada akhir tahun 2015 bahkan beberapa bank mengalami pencapaian ROA di bawah 0\%. Bank Bank Harda dan Bank Pundi merupakan salah satu bank yang mengalami penurunan cukup drastis dari tahun sebelumnya yaitu sebesar $200 \%$ dan $330 \%$. Secara keseluruhan selama periode 20142015 pergerakan profitabilitas kembali menunjukan tren yang menurun di bawah standar ketentuan Bank Indonesia yaitu dengan rata-rata pencapaian sebesar $0,8 \%$ dan $0,17 \%$. Sedangkan posisi pencapaian ROA tertinggi diraih oleh Bank BTPN selama lima tahun berturut-turut. Sembilan dari sepuluh BUSN Non Devisa Go Public masih berada pada ratarata pencapaian ROA di bawah $1,5 \%$ setiap tahunnya selama periode 2011-2015. Gambaran atau analisis mengenai perkembangan profitabilitas yang terjadi pada BUSN Non Devisa Go Public periode 2011-2015 di atas, dapat menjadi acuan bagi manajemen perusahaan untuk mengambil langkah-langkah perbaikan yang diperlukan.

Hasil penelitian secara empiris menunjukan bahwa Kredit Bermasalah berpengaruh terhadap Profitabilitas, sehingga hipotesis yang diajukan penulis yaitu bahwa Kredit Bermasalah berpengaruh terhadap Profitabilitas sesuai dan dapat diterima. Berikut adalah hasil penelitian empiris kondisi Kredit Bermasalah terhadap harga Profitabilitas. Uji Fstat merupakan model yang cukup baik untuk digunakan karena hasil regresi data $F_{\text {hitung }}>F_{\text {tabel }}$ yaitu 6,90 > 4,04 dengan tingkat prob $<0,05$ $(0,00004)$. Nilai Adjusted $R^{2}$ menunjukan sejauh mana variasi dari variabel terikat mampu dijelaskan oleh variabel bebasnya, atau dengan kata lain bagaimana model dapat menjelaskan pergerakan variabel terikatnya. Nilai Adjusted $R^{2}$ berkisar antara 0-1, semakin mendekati 1 maka kemampuan model menjelaskan pergerakan variabel terikat semakin baik. Hasil estimasi model yang digunakan menghasilkan nilai Adjusted $R^{2}$ sebesar 0,546317. Nilai ini menunjukan model yang digunakan dapat menjelaskan variabel terikat atau return on assets sebesar 54,63\%. Sedangkan koefisien dan t-stat variabel independent dapat dijelaskan dengan uji signifikasi dan uji dua arah ROA terhadap variabel NPL. Variabel independen Non Performing Loan (NPL) memiliki (prob) < $\alpha(\alpha=5 \%)$, karena $t_{\text {hitung }}>t_{\text {tabel }}$ yaitu $4,586>2,009$ dengan tingkat prob $<0,05(0,00004)$ maka tolak $\mathrm{H}_{0}$. Berarti variabel NPL berhubungan secara signifikan terhadap ROA. Koefisien NPL yang bertanda negarif menunjukan hubungan antar variabel NPL dan ROA tidak searah atau berbanding terbalik. Saat NPL naik, maka ROA akan semakin turun. Nilai koefisien dari NPL menggambarkan bahwa kenaikan NPL sebesar $1 \%$ akan menurunkan ROA sebesar 0,418830 dan begitu juga sebaliknya.

\section{KESIMPULAN DAN REKOMENDASI}

Berdasarkan hasil penelitian yang telah dilakukan menggunakan analisis deskriptif nilai rata-rata NPL pada tahun 2011 yaitu sebesar 2,68\%, tahun $20122,43 \%$, tahun 2013 mengalami penurunan menjadi $1,78 \%$, tahun 2014 kembali meningkat menjadi 2,47\%, dan tahun 2015 sebesar 2,50\%. Rata-rata perhitungan tersebut merupakan gabungan dari sepuluh BUSN Non Devisa, sedangkan analisis berdasarkan masing-masing bank masih menunjukan nilai NPL yang cukup tinggi, sehingga dapat disimpulkan bahwa BUSN Non Devisa Go Public periode 2011-2015 belum mencapai kinerja keuangan yang baik dilihat dari besarnya kredit bermasalah (NPL) yang dimilikinya.

Rata-rata nilai ROA Bank Artos sepanjang periode analisis yaitu sebesar $0,332 \%$, Bank Harda sebesar 0,42\%, Bank Ina Perdana sebesar 0,93\%, Bank Mitraniaga sebesar 0,51, Bank Pundi sebesar $-1,88 \%$, dan Bank Yudha Bakti sebesar $0,86 \%$. Temuan ini menggambarkan nilai-nilai tersebut masih berada di bawah target minimal berdasarkan 
regulasi bahkan berada pada nilai negatif yang berarti mengalami kerugian. Pada Bank BTPN nilai rata-rata sepanjang periode analisis yaitu sebesar 4,06\%, Bank Dinar Indonesia berada pada nilai rata-rata $1,46 \%$, Bank Multiarta Sentosa sebesar 2,16\%, dan Bank Victoria sebesar 1,64\%. Bank tersebut merupakan bank yang masih dapat mempertahankan nilai ROA di atas target regulasi Bank Indonesia yaitu 1,5\%. Deskripsi berdasarkan durasi waktu per tahun masa kerja diperoleh perbandingan antara profitabilitas yang sehat dan tidak sehat dengan

\section{DAFTAR PUSTAKA}

Adagye, D. I. (2015). Effective Working Capital Management And The Profitability Of Quoted Bank In Nigeria. European Journal Of Accounting Auditing And Finance Research, 3(2), 97-107.

Adeusi, S. O., \& Kolapo, F. T. (2014). Determinants Of Commercial Banks, Profitability. International Journal of Economics, Commerce And Management, 2(12), 1-18.

Ali, A. (2016). Pengaruh Struktur Modal Terhadap Profitabilitas Pada Perusahaan Telekomunikasi. Jurnal Ilmu \& Riset Manajemen, 4(9), 1-20.

Arbi, S. (2013). Perbankan Lembaga Keuangan Dan Pembiayaan (1st Ed.). Yogyakarta: Bpfe.

Asli Demirguc-Kunt And Harry Huizinga. (2000). Financial Structure And Bank Profitability. Structure, (January), 1-24. Https://Doi.Org/Doi:10.1596/1813-94502430

Becker, B., \& Ivashina, V. (2014). Cyclicality Of Credit Supply: Firm Level Evidence \$. Journal Of Monetary Economics, 62, 76-93.

Https://Doi.Org/10.1016/J.Jmoneco.2013 .10 .002

Berrada, A., Loudiyi, K., \& Zorkani, I. (2017). Profitability, Risk, And Financial Modeling Of Energy Storage In Residential And Large Scale Applications. Energy, 119, 94-109. Https://Doi.Org/10.1016/J.Energy.2016.1 2.066

Bougatef, K. (2017). Determinants Of Bank Profitability In Tunisia: Does Corruption angka perbandingan 3:2, di mana 3 tahun kondisi profitabilitas tidak sehat, sedangkan 2 tahun profitabilitas berada dalam kondisi sehat. Sehingga dapat disimpulkan bahwa perkembangan Return On Asset (ROA) BUSN Non Devisa Go Public periode 2011-2015 kurang baik.

Adanya penelitian ini diharapkan dapat membantu peneliti berikutnya dalam melakukan penelitian mengenai Kredit Bermasalah, Non Performing Loan (NPL), Profitabilitas, Retun On Asset (ROA).

\section{Matter? Journal Of Money Laundering Control, 20(1), 70-78. Https://Doi.Org/10.1108/Jmlc-10-2015- 0044}

Brigham, Eugene F. Houton, J. F. (2014). Fundamentals Of Finance Management r(14th Ed.). Jakarta: Salemba Empat.

Dalabeeh, A.-R. E.-. (2013). The Role Of Financial Analysis Ratio In Evaluating Performance ( Case Study : National Chlorine Industry ). Interdisciplinary Journal Of Contemporary Research In Business June, 5(June), 13-28.

Dash,M.K \& Kabra, G. (2010). “ Determinants Of Non-Performing Loans - Evidence From Southeastern European Banking Systems " Determinants Of NonPerforming Loans - Evidence From Southeastern European Banking Systems. Middle Eastern Finance And Economics, 39(1), 1-13.

Dendawijaya, L. (2009). Manajemen Perbankan (2nd Ed.). Jakarta.Indonesia: Ghalia.

Devi, M. S. R. I. (2011). Perusahaan Kimia \& Farmasi Yang Terdaftar Di Bursa Efek Indonesia Tahun 2008-2011. Jurnal Akuntansi \& Keuangan.

Duraj, B., \& Moci, E. (2015). Factors Influencing The Bank ProfitabilityEmpirical Evidence From Albania. Asian Economic And Financial Review, 5(3), 483-494. Https://Doi.Org/10.18488/Journal.Aefr/2 015.5.3/102.3.483.494

Gitman Chad, L. J. And J. D. M. (2014). Fundamental Of Investing (11th Ed.). Boston: Pearson, Addision Wesley. 
Goddard, J., Molyneux, P., \& Wilson, J. O. S. (2008). Dynamics Of Growth And Profitability In Banking Dynamics Of Growth And Profitability In Banking, 36(6), 1069-1090.

Golin, J. P. D. (2013). The Bank Credit Analysis Handbook: A Guide For Analysts, Bankers And Investors (2nd $E d$.). New York, Ny.

Haneef, S., Rana, M. A., \& Karim, Y. (2012). Impact Of Risk Management On NonPerforming Loans And Profitability Of Banking Sector Of Pakistan Hailey College Of Commerce University Of The Punjab Hafiz Muhammad Ishaq Federal Urdu University Of Arts, Science And Technology. International Journal of Business And Social Science, 3(7), 307315.

Haron, S., \& Azmi, W. N. (2004). Profitability Determinants Of Islamic Banks : A Cointegration Approach. Islamic Banking Conferrence, Union Arab Bank, 4(December), 2-18.

Heffernan, S. (2005). Modern Banking. (J. \& S. Wiley, Ed.). London: Professor Of Banking And Finance Cass Busniness School. Retrieved From Www.Wileyeurope.Com

Hester, D. D. And J. F. Z. (1966). The Relation Between Bank Portofolios And Earnings : An Econometric Analysis.

Husnan, S. \& E. P. (2006). Dasar Manajemen Keuangan. Yogyakarta: Upp Stim Ykpn.

Innocent, E. C., Mary, O. I., \& Matthew, O. M. (2013). Financial Ratio Analysis As A Determinant Of Profitability In Nigerian Pharmaceutical Industry, 8(8), 107-117. Https://Doi.Org/10.5539/Ijbm.V8n8p107

Ishaq, A. B., Karim, A., Zaheer, A., \& Ahmed, S. (2015). Evaluating Performance Of Commercial Banks In Pakistan: “ An Application Of Camel Model " Abdul Basit Ishaq Abdul Karim Adnan Zaheer Sohail Ahmed Mb-F11-200017 Specialization In Finance Army Public College Of Management \& Sciences ( Apcoms ) Khadim Hussa.

Iskandar, S. (2013). Bank Dan Lembaga Keuangan Lainnya (1st Ed.). Jakarta: In Media.
Ismail. (2011). Manajemen Perbankan Dari Teori Menuju Aplikasi (1st Ed.). Jakarta: Kencana Perdana Media Group.

Jewell, J. J., \& Mankin, J. A. (2011). What Is Your Roa? An Investigation Of The Many Formulas For Calculating Return On Assets. Academy Of Educational Leadership Journal, 15(1980), 79-91.

Kasmir. (2015). Analisis Laporan Keuangan (8th Ed.). Jakarta: Raja Grafindo Persada.

Lesáková, L'. (2007). Uses And Limitations Of Profitability Ratio Analysis In Managerial Practice. International Conference On Management, ..., (June), 259-264. Retrieved From Http://Kgk.UniObuda.Hu/System/Files/24_Lesakova.Pd $\mathrm{f}$

Lukman, S. (2009a). Manajemen Keuangan Perusahaan: Konsep Aplikasi Dalam Perencanaan,Pengawasan, Dan Pengambilan Keputusan (Baru). Jakarta: Pt.Raja Grafindo Persada.

Lukman, S. (2009b). Manajemen Keuangan Perusahaan. Aplikasi Dalam Perencanaan,Pengawasan, Dan Pengambilan Keputusan (Baru). Jakarta: Pt.Raja Grafindo Persada.

Masood, O., \& Ashraf, M. (2012). BankSpecific And Macroeconomic Profitability Determinants Of Islamic Banks: The Case Of Different Countries. Qualitative Research In Financial Markets, 4(2/3), 255-268. Https://Doi.Org/10.1108/1755417121125 2565

Mehta, A., \& Bhavani, G. (2017). What Determines Banks' Profitability? Evidence From Emerging Markets The Case Of The Uae Banking Sector, 6(1), 77-88. Https://Doi.Org/10.5430/Afr.V6n1p77

Molyneux, P., \& Thornton, J. (1992). Determinants Of European Bank Profitability: A Note. Journal Of Banking And Finance, 16(6), 1173-1178. Https://Doi.Org/10.1016/03784266(92)90065-8

Munawir. (2014). Analisa Laporan Keuangan (17th Ed.). Yogyakarta: Liberty.

Nawaz, Muhammad., And Munir, S. (2012). 
Credit Risk And The Performance Of Nigerian Banks. Interdisciplinary Journal Of Contemporary Research In Business2, 4(7), 49-63.

Olson, D., \& Zoubi, T. A. (2011). Efficiency And Bank Profitability In Mena Countries. Emerging Markets Review, 12(2), 94-110.

Https://Doi.Org/10.1016/J.Ememar.2011. 02.003

Onuonga, S. M. (2014). The Analysis Of Profitability Of Kenya `S Top Six Commercial Banks : Internal Factor Analysis, 3(5), 94-103.

Rivai, V. E. Al. (2013). Commercial Bank Management Dari Teori Ke Praktek. Jakarta: Pt.Raja Grafindo Persada.

Srinivasan, T., \& Thiru, M. (2015). An Empirical Study Of Profitability Analysis Of Neyveli Lignite Corporation Limited ( Nlc Ltd .) Deputy Director And Associate Professor Of Commerce, Dde . Annamalai University, Annamalai Nagar , Tamil Nadu Assistant Professor Of Commerce, Dde ., Annam. Global Journal For Research Analysis, 4(6), 162-163.

Sriyana, J. (2015). Islamic Banks ' Profitability Amid The, 13(4), 1695-1710.

Surachim, A. (2010). Pengaruh Penyaluran Kredit ( Loan ) Terhadap Profitabilitas ( Studi Kasus Pada Laporan Keuangan Pt Bank Mega Tbk ). Strategic Jurnal Pendidikan Manajemen Bisnis, 9(18), 40-48.

Swamy, V. (2013). Determinants Of Bank Asset Quality And Profitability - An Empirical Assessment. Economics The Open-Access, Open Assessment EJournal, Discussion Paper No. 2015-27, Personal,(47513), 1-43. Https://Doi.Org/10.2139/Ssrn.2126761
Tiberiu, C. (2015). Banks ' Profitability And Financial Soundness Indicators: A Macro- Level Investigation In Emerging Countries. Procedia Economics And Finance, 23(October 2014), 203-209. Https://Doi.Org/10.1016/S22125671(15)00551-1

Trad, N., Trabelsi, M. A., \& Goux, J. F. (2016). Risk And Profitability Of Islamic Banks: A Religious Deception Or An Alternative Solution? European Research On Management And Business Economics, 1-6. Https://Doi.Org/10.1016/J.Iedeen.2016.0 9.001

Van Horne, J. C. (2016). Prinsip-Prinsip Manajemen Keuangan. (E. S. Suharsi, Ed.) (13th Ed.). Jakarta: Salemba Empat.

Weon Lee, S. (2015). Capital Strength And Bank Profitability. Asian Social Science, 11(10), 120-125. Https://Doi.Org/10.5539/Ass.V11n10p12 0

Wild, J. \& K. R. S. (2010). Financial Statment Analysis. Usa: Mcgraw-Hill International Edition.

Yazdanfar, D. (2013). Profitability Determinants Among Micro Firms: Evidence From Swedish Data. International Journal Of Managerial Finance, 9(2), 151-160. Https://Doi.Org/10.1108/1743913131130 7565

Yazdanfar, D., \& Öhman, P. (2016). The Impact Of Trade Credit Use On Firm Profitability: Empirical Evidence From Sweden. Journal Of Advances In Management Research, 13(2), 116-129. Https://Doi.Org/Doi:10.1108/Jamr-092015-0067 